\title{
Proton exchange membrane fuel cells with chromium nitride nanocrystals as electrocatalysts
}

Hexiang Zhong

Key Materials Laboratory for PEMFCs, Dalian Institute of Chemical Physics, Chinese Academy of Sciences, Dalian 116023, China. And Graduate School of the Chinese Academy of Sciences, Beijing, 100039, China.

\section{Xiaobo Chen}

Lawrence Berkeley National Laboratory, University of California, Berkeley, CA 94720 , USA

Huamin Zhang, * Meiri Wang

Key Materials Laboratory for PEMFCs, Dalian Institute of Chemical Physics, Chinese Academy of Sciences, Dalian 116023, China.

Samuel S. Mao*

Lawrence Berkeley National Laboratory, University of California, Berkeley, CA 94720, USA

*Corresponding Authors:

Huamin Zhang, E-mail: Zhanghm@dicp.ac.cn

Samuel S. Mao, E-mail: SSMao@lbl.gov 


\begin{abstract}
Polymer electrolyte membrane fuel cells (PEMFCs) are energy conversion devices that produce electricity from a supply of fuel, such as hydrogen. One of the major challenges in achieving efficient energy conversion is the development of cost-effective materials that can act as electrocatalysts for PEMFCs. In this letter, we demonstrate that, instead of conventional noble metals, such as platinum, chromium nitride nanocrystals of fcc structure exhibit attractive catalytic activity for PEMFCs. Device testing indicates good stability of nitride nanocrystals in low temperature fuel cell operational environment.
\end{abstract}


As clean energy conversion devices, polymer electrolyte membrane fuel cells (PEMFCs) have many advantages, including high energy conversion efficiency, which make them attractive for both mobile and stationary applications. ${ }^{1,2}$ Platinum $(\mathrm{Pt})$ has been regarded as the most active catalyst for oxygen reduction reaction, and thus is widely used to construct the cathode of PEMFCs. ${ }^{3-5}$ However, the ultimate applications of PEMFCs are hindered, at least partially, due to the high cost of the noble material. ${ }^{6}$ Although much progress has been made in reducing Pt usage in the fuel cell anode, lowering the cathode Pt loading generally results in reduced fuel cell efficiency. ${ }^{7}$ Alloying Pt with metals such as $\mathrm{Fe}, \mathrm{Co}, \mathrm{Ni}$, and $\mathrm{Cu}$ has been attempted; however, nonnoble metals in these alloys are usually etched easily in the acid environment of PEMFCs. Therefore, development of unconventional, non-noble catalytic materials that can potentially substitute for Pt is critical for cost-effective fuel cell devices.

Transition metal chalcogenides, ${ }^{8,9}$ metal oxides, ${ }^{10}$ and macrocycles such as porphyrin or phthalocyanine ${ }^{11}$ have been proposed as alternatives to replace noble metals in PEMFCs. Since Levy and Boudart ${ }^{12}$ reported Pt-like properties of tungsten carbide, carbides and nitrides have been investigated as potential electrocatalysts. ${ }^{13-15}$ Among different metal nitrides, TiN is the most widely studied, ${ }^{16}$ but it suffers from wear and corrosion in acid environment, in addition to low catalytic activity. In contrast, chromium nitrides such as $\mathrm{CrN}$ and $\mathrm{Cr}_{2} \mathrm{~N}$ have high resistance to wear and corrosion. ${ }^{17},{ }^{18}$ In this letter, we demonstrate that highly crystalline $\mathrm{CrN}$ nanoparticles of fcc structure exhibit attractive catalytic activity and stability for the oxygen reduction reaction in PEMFCs. 
This result offers a possible solution to the need of cost-effective electrocatalyst alternatives for fuel cells.

$\mathrm{CrN}$ nanocrystals supported on carbon particles (Vulcan XC-72R, Cabot Corp.) were prepared as follows. Carbon particles were impregnated with $\mathrm{Cr}\left(\mathrm{NO}_{3}\right)_{3} \cdot 6 \mathrm{H}_{2} \mathrm{O}$ dissolved in water, which were dried at $80{ }^{\circ} \mathrm{C}$ for $12 \mathrm{~h}$ and calcined for $2 \mathrm{~h}$ at $500{ }^{\circ} \mathrm{C}$ in $\mathrm{N}_{2}$ atmosphere. The as-formed powders were treated under $\mathrm{NH}_{3}$ atmosphere at high temperature for $2 \mathrm{~h}$, and then cooled to room temperature. Fig. 1A shows X-ray diffraction patterns of $\mathrm{CrN}$ on carbon $(18 \mathrm{wt} . \% \mathrm{Cr})$ treated at different temperatures: (a) $800{ }^{\circ} \mathrm{C}$, (b) $900{ }^{\circ} \mathrm{C}$, and (c) $950{ }^{\circ} \mathrm{C}$. All chromium nitride nanocrystals displayed a single fcc CrN phase. Transmission Electron Microscope (TEM) studies found that most of the CrN nanocrystals were dispersed over the surface of the carbon particles with diameters ranging from 8 to $30 \mathrm{~nm}$. Fig. 1B shows two TEM images of $\mathrm{CrN}$ on carbon prepared at $800{ }^{\circ} \mathrm{C}$. The formation of relatively large particles could be due to agglomeration of smaller ones when calcinated at high temperature during the preparation process. Highresolution TEM image revealed the highly crystalline nature of $\mathrm{CrN}$ nanocrystals, with a typical hexagonal profile as shown in the inset of Fig. 1B.

Fuel cell device tests were conducted with $5 \mathrm{~cm}^{2}$ membrane electrode assemblies (MEAs) using $\mathrm{CrN}$ nanocrystals as the cathode electrocatalyst (Pt was used at the anode). Nafion-1035 (Du Pont) was used as the fuel cell membrane, and the CrN catalysts were mixed with isopropanol and $5 \%$ Nafion solution suspension $(\mathrm{CrN} / \mathrm{C}$ : Nafion $=2: 1$ by dried weight) to form an ink-like slurry. The slurry was cast onto a prefabricated gas 
diffusion layer and heat-treated at $130{ }^{\circ} \mathrm{C}$ in a vacuum oven to obtain the cathode electrode. The membranes were boiled in $3 \% \mathrm{H}_{2} \mathrm{O}_{2}$ solution and in $0.5 \mathrm{M} \mathrm{H}_{2} \mathrm{SO}_{4}$ to remove organic and mineral impurities, and then rinsed with hot distilled water. The treated membrane was sandwiched between two gas diffusion layers followed by a hotpressing procedure at $140{ }^{\circ} \mathrm{C}$ and $10 \mathrm{MPa}$ to form a MEA. The temperature of the fuel cell devices was kept at $80^{\circ} \mathrm{C}$, and the fuel $\left(\mathrm{H}_{2}\right)$ and the oxidant $\left(\mathrm{O}_{2}\right)$ were humidified by passing them through water bathes at temperatures of $90{ }^{\circ} \mathrm{C}$ and $85{ }^{\circ} \mathrm{C}$, respectively. Performance data were recorded in the steady state.

Fig. 2 shows the performance of fuel cell devices with cathode electrocatalysts prepared under different conditions. Lower temperature processes appear to yield better device performance. With $\mathrm{CrN}$ nanocrystals prepared at $800{ }^{\circ} \mathrm{C}, 900{ }^{\circ} \mathrm{C}$ and $950{ }^{\circ} \mathrm{C}$, the cell voltages are $0.305,0.289$, and $0.275 \mathrm{~V}$, respectively, at a current density of $100 \mathrm{~mA}$ $\mathrm{cm}^{-2}$. The corresponding maximum power density, Wmax, are $44.67 \mathrm{mWcm}^{-2}, 39.4$ $\mathrm{mWcm}^{-2}$ and $34.6 \mathrm{mWcm}^{-2}$, respectively. The increase of the device performance can be attributed to increased electrochemically active surfaces with smaller nanocrystal size when prepared at lower temperature. On the other hand, better performance was obtained with higher $\mathrm{CrN}$ nanocrystal loading of the cathode. The Wmax increased from 38.84 $\mathrm{mWcm}^{-2}$ to $53.66 \mathrm{mWcm}^{-2}$, and cell voltage increased from $0.240 \mathrm{~V}$ to $0.318 \mathrm{~V}$ at the current density of $100 \mathrm{~mA} \mathrm{~cm}$, when the loading was increased from $0.42 \mathrm{mg} \mathrm{cm}^{-2}$ to $1.08 \mathrm{mg} \mathrm{cm}^{-2}$. 
The sources of the resistance of the fuel cell devices were studied with the electrochemical impedance spectra (EIS). The EIS spectra in Fig. 3A showed that the semicircle was made of two high frequency capacitive loops. The simulated data using equivalent circuits suggested that the resistance at high frequency, as well as the resistance related to electrode structure, remained almost constant when the current increased from $0.5 \mathrm{~A}$ to $1.5 \mathrm{~A}$. The charge-transfer resistance for oxygen reduction and associated catalyst layer capacitance decreased from $245.6 \mathrm{~m} \Omega$ to $111.2 \mathrm{~m} \Omega$, which indicates that the kinetics of oxygen reduction become faster and contribute to the increase of the cell performance with increased current. However, the value of internal resistance was higher than that of normal Pt-based MEAs. ${ }^{19}$ As shown in Fig. 3B, when saturated with $\mathrm{N}_{2}$, the anodic and cathodic electric charges were almost equal, which were responsible for the charge and discharge of an electric double layer. No specific peak due to anodic dissolution was observed in the cyclic voltammetry measurements. This indicated that $\mathrm{CrN}$ nanocrystals had a high electrochemical stability in acidic solution between the scanned potential ranges. When saturated with $\mathrm{O}_{2}$, the current increased for the electrode, due to the electro-reduction of oxygen. The reaction started at a relatively positive potential, about $0.46 \mathrm{~V}$, which could be attributed to a change in the electron distribution in chromium by addition of nitrogen. ${ }^{12,20}$ This resulted in the creation of base and/or acid sites and yields Pt-like catalytic activity. ${ }^{21}$

To summarize, our measurements have demonstrated that metal nitrides could play an important role in the development of unconventional, non-noble electrocatalysts for cost-effective fuel cell devices. In particular, CrN nanocrystals displayed attractive Pt- 
like catalytic activity and stability for PEMFCs. Additional experiments on the reaction kinetics of $\mathrm{CrN}$-based electrode were performed using rotating disk-ring electrode approach, which indicated a combined kinetic-diffusion mechanism of charge and mass transport. Based on Koutecky-Levich analysis, ${ }^{22}$ the oxygen was partially reduced to $\mathrm{H}_{2} \mathrm{O}$ via the four-electron route at the $\mathrm{CrN}$ electrode, and partially reduced to $\mathrm{H}_{2} \mathrm{O}_{2}$ and then $\mathrm{H}_{2} \mathrm{O}$ via the two-electron route. Although the catalytic activity of $\mathrm{CrN}$ nanocrystals is somewhat lower than that of Pt, their resource is abundant in addition to their much lower cost. Optimization in nitride preparation processes including composition variations could potentially enhance their catalytic activity, which makes nitride nanocrystals promising for PEMFCs.

\section{Acknowledgements:}

We acknowledge support from National Natural Science Foundation of China, Lawrence Berkeley National Laboratory, and the National Center for Electron Microscopy, which is funded by the U.S. Department of Energy under Contract \# DEAC02-05CH11231. 


\section{Reference}

1 S. Litster, N. Djilali, Electrochim. Acta 52, 3849 (2007).

2 X. G. Yang, C. Y. Wang, Appl. Phys. Lett. 86, 224104 (2005).

3 G. Chen, D. G. Xia, Z. R. Nie, Z. Y. Wang, L. Wang, L. Zhang, J. J. Zhang, Chem. Mater. 19, 1840 (2007).

4 K. Kinoshita, J. A. S. Bett, Carbon 11, 403 (1975).

5 Z. Q. Tian, S. P. Jiang, Y. M. Liang, P. K. Shen, J. Phys. Chem. B 110, 5343 (2006).

6 S. S. Mao, X. B. Chen, Int. J. Energy Res. 31, 619 (2007).

7 H. A. Gasteiger, S. S. Kocha, B. Sompalli, F.T. Wagner, Appl. Catal. B: Environm. 56, 9 (2005).

8 D. Cao, A. Wieckowski, J. Inukai, N. Alonso-Vante, J. Electrochem. Soc. 153, A869 (2006).

9 K. C. Lee, L. Zhang, J. J. Zhang, Electrochem. Commun. 9, 1704 (2007).

10 R. W. Reeve, P. A. Christensen, A. J. Dickinson, A. Hamnett, K. Scott, Electrochim. Acta 45, 4237 (2000).

11 R. Bashyam, P. Zelenay, Nature 443, 63 (2006).

12 R. B. Levy, M. Boudart, Science 181, 547 (1973).

13 R. Venkataraman, H. R. Kunz, J. M. Fenton, J. Electrochem.Soc. 150, A278 (2003).

14 S. Arico, S. Srinivasan, V. Antonucci, Fuel Cells 1, 133 (2001).

15 Y. Hara, N. Minami, H. Itagaki, Appl. Catal. A: General 323, 86 (2007).

16 F. Mazza, S. Trassatti, J. Electrochem. Soc. 110, 847 (1963).

17 J. M. Lacknera, W. Waldhausera, B. Majorb, J. Morgielb, L. Majorb, H. Takahashic, 
T. Shibayama, Surf. Coat. Tech. 200, 3644 (2006).

18 K. Volz, M. Kiuchi, W. Ensinger, Surf. Coat. Tech. 108, 303 (1998).

19 O. Antoine, Y. Bultel, R. Durand, J. Electroanal. Chem. 499, 85 (2001).

20 G. Soto, W. de la Cruz, F. F. Castillon, J. A. Diaz, R. Machorro, M. H. Farias, Appl. Surf. Sci. 214, 58 (2003).

21 L. H. Bennett, J. R. Cuthill, A. J. Mcalister, N. E. Erickson, R. E. Watson, Science 184, 563 (1974).

22 M. S. El-Deab, T. Ohsaka, Electrochim. Acta 47, 4255 (2002). 


\section{Figure Captions}

Figure 1. (A) X-ray diffraction patterns of the PEMFC catalyst $\mathrm{CrN} / \mathrm{C}$ treated at different temperature (a) $800{ }^{\circ} \mathrm{C}$; (b) $900{ }^{\circ} \mathrm{C}$; (c) $950{ }^{\circ} \mathrm{C}$. (B) $\mathrm{TEM}$ images of $\mathrm{CrN} / \mathrm{C}$ prepared at $800{ }^{\circ} \mathrm{C}$. The inset shows a high resolution TEM image of a single CrN nanocrystal.

Figure 2. (A) Polarization curves of fuel cell devices with $\mathrm{CrN}$ loading of $0.5 \mathrm{mg}$ $\mathrm{cm}^{-2}$ prepared at different temperatures: (a) $800{ }^{\circ} \mathrm{C}$; (b) $900{ }^{\circ} \mathrm{C}$; (c) $950{ }^{\circ} \mathrm{C}$. (B) Polarization curves with different $\mathrm{CrN}$ loadings: (a) $0.42 \mathrm{mg} \mathrm{cm}^{-2}$; (b) $0.5 \mathrm{mg} \mathrm{cm}^{-2}$; (c) $1.08 \mathrm{mg} \mathrm{cm}^{2}$ at $800{ }^{\circ} \mathrm{C}$.

Figure 3. (A) EIS of fuel cell devices with $\mathrm{CrN} / \mathrm{C}$ prepared at $800{ }^{\circ} \mathrm{C}$ at different current (cell temperature $80{ }^{\circ} \mathrm{C}$ ). Legend specifies current of the experiments. (B) Cyclic voltammetry curves for $\mathrm{CrN} / \mathrm{C}$ in $0.5 \mathrm{M} \mathrm{H}_{2} \mathrm{SO}_{4}$ solution at a rotating rate of $900 \mathrm{rpm}$. (a) Saturated with nitrogen (b) saturated with oxygen. Scan rate $=5$ $\mathrm{mV} \mathrm{s}^{-1}$, at $25^{\circ} \mathrm{C}$. 

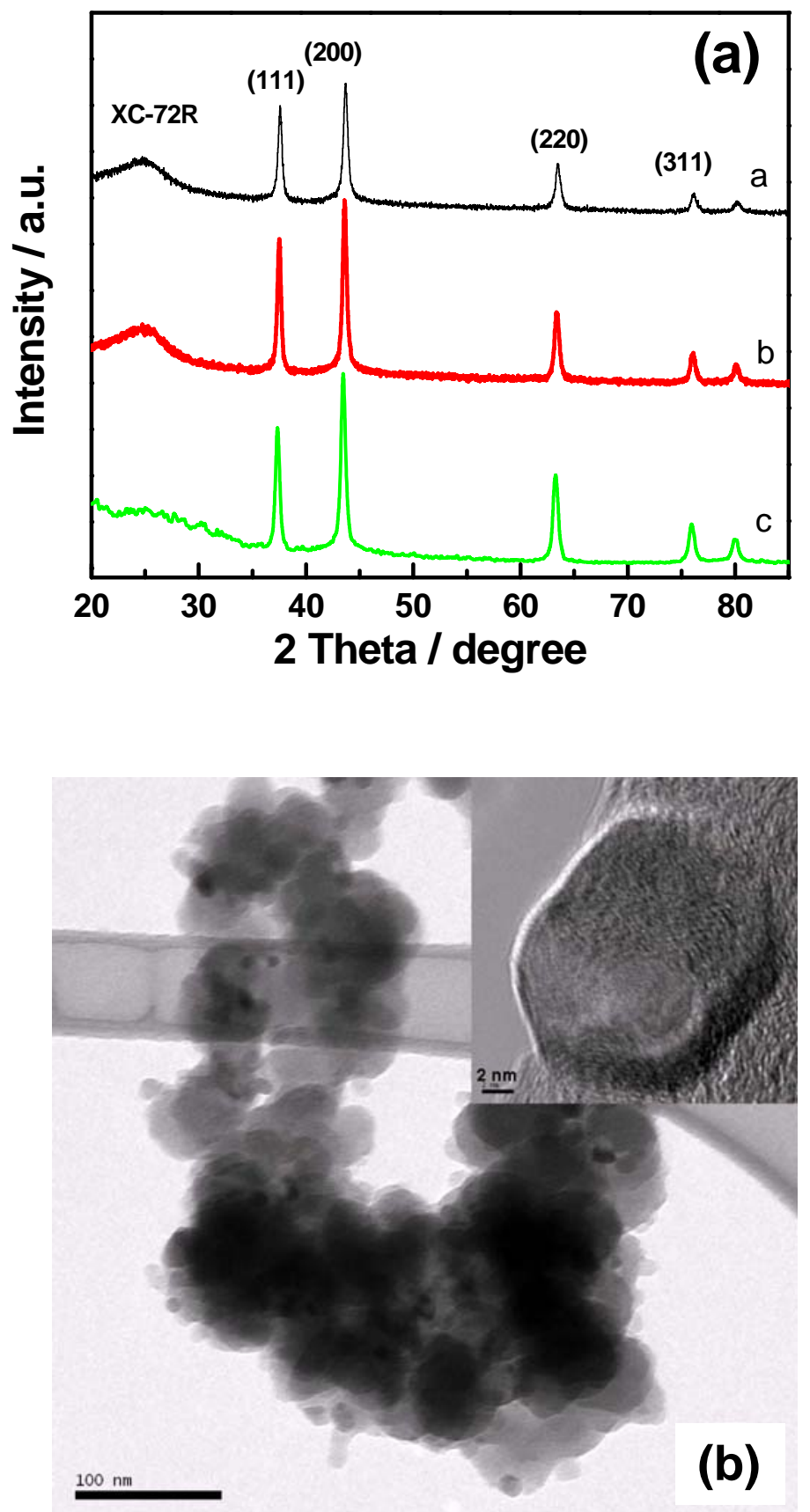

Figure 1 

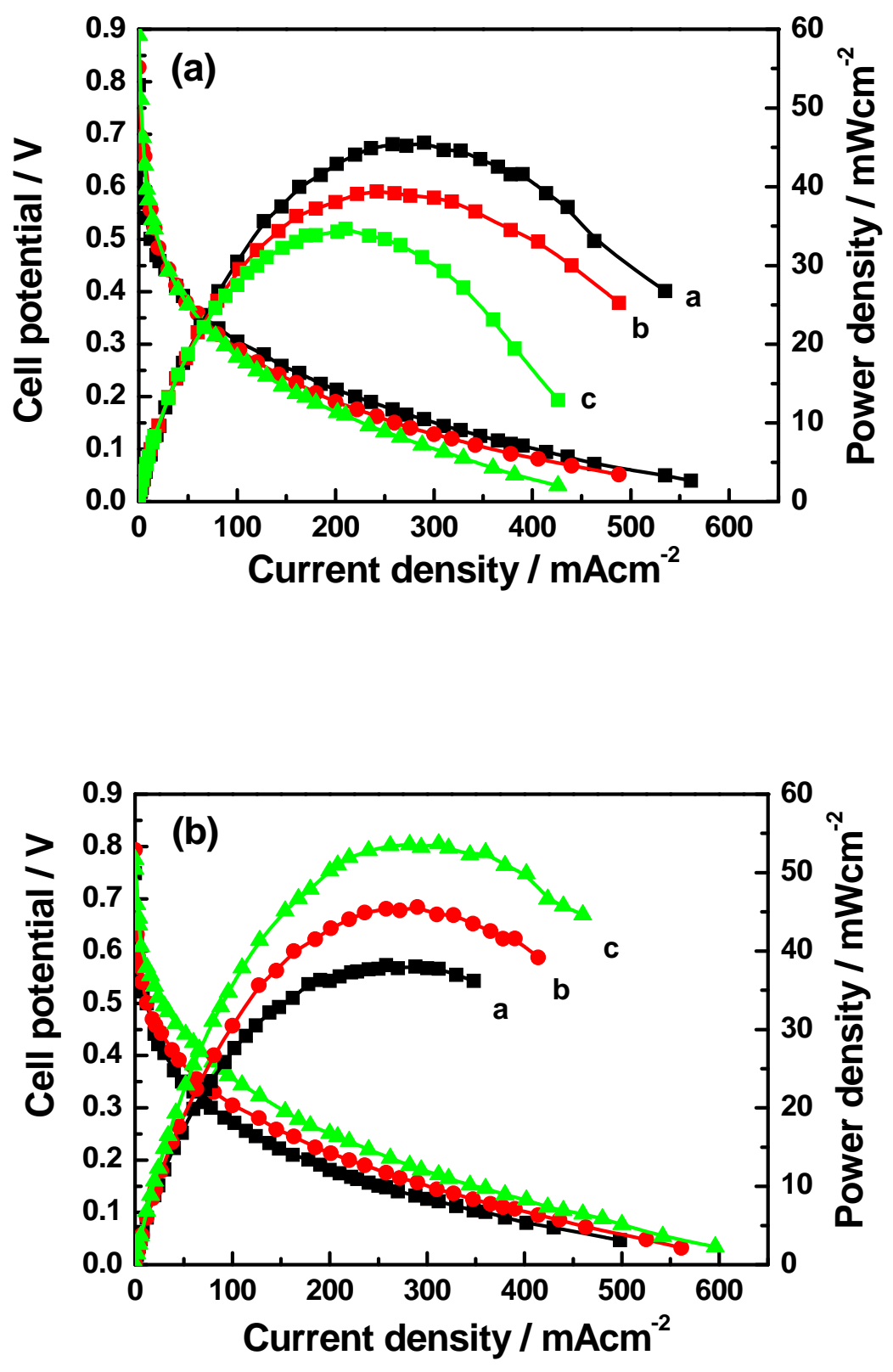

Figure 2 

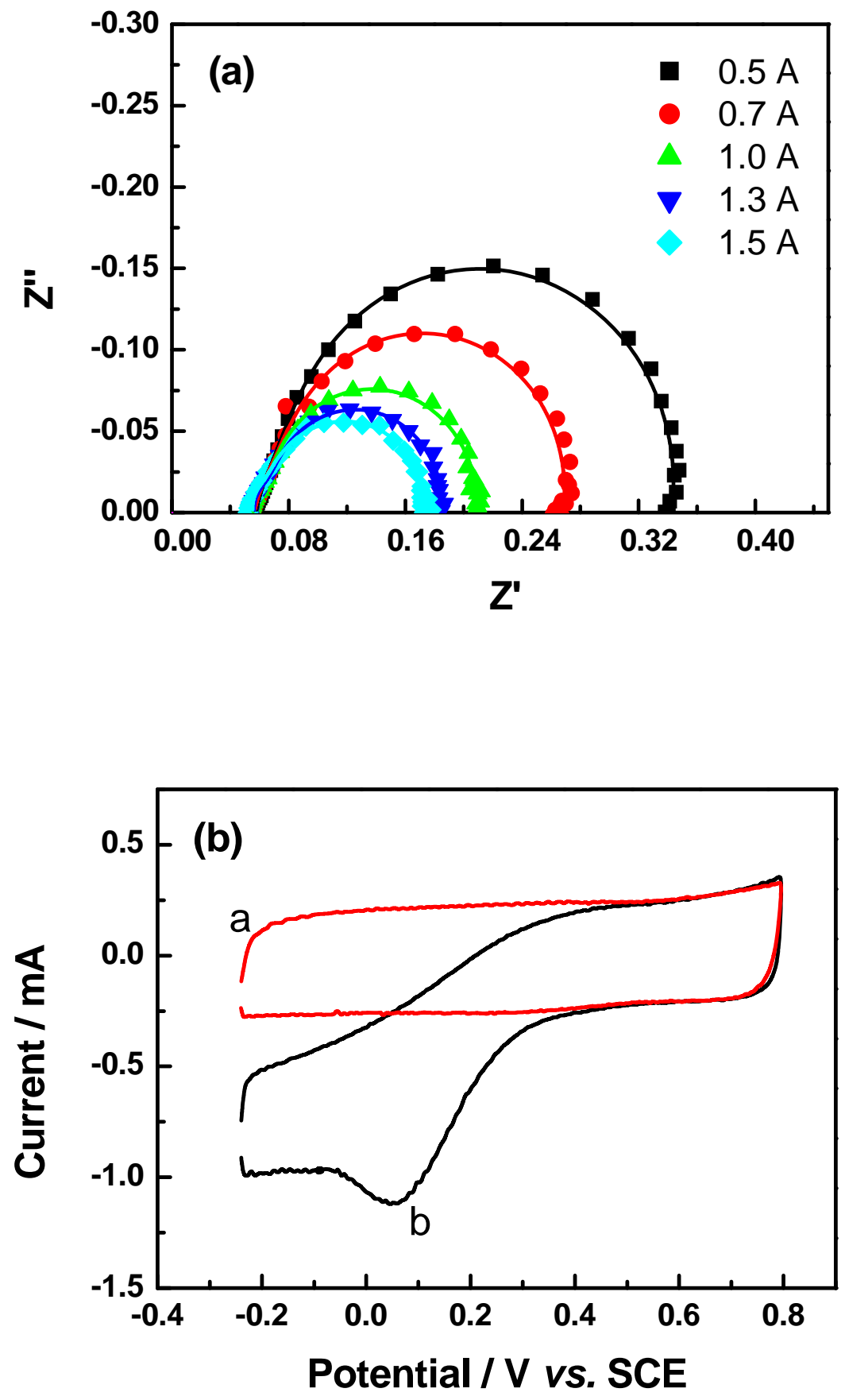

Figure 3 